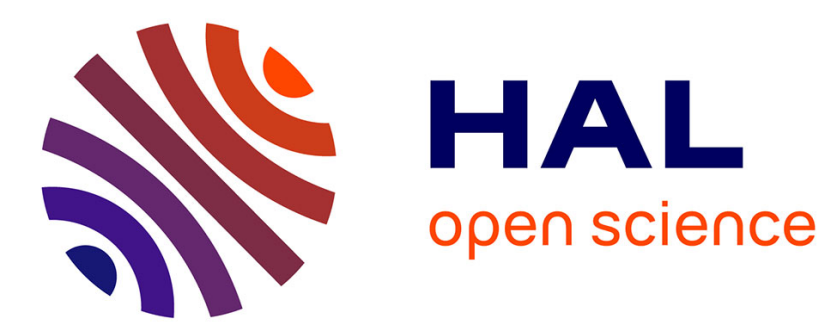

\title{
THE INTRODUCTION OF EMERGING CURRENCIES INTO A PORTFOLIO: TOWARDS A MORE COMPLETE DIVERSIFICATION MODEL
}

Sophie Brana, Stéphanie Prat

\section{To cite this version:}

Sophie Brana, Stéphanie Prat. THE INTRODUCTION OF EMERGING CURRENCIES INTO A PORTFOLIO: TOWARDS A MORE COMPLETE DIVERSIFICATION MODEL. 2009. hal00616581v2

\author{
HAL Id: hal-00616581 \\ https://hal.science/hal-00616581v2
}

Preprint submitted on 28 Nov 2011

HAL is a multi-disciplinary open access archive for the deposit and dissemination of scientific research documents, whether they are published or not. The documents may come from teaching and research institutions in France or abroad, or from public or private research centers.
L'archive ouverte pluridisciplinaire HAL, est destinée au dépôt et à la diffusion de documents scientifiques de niveau recherche, publiés ou non, émanant des établissements d'enseignement et de recherche français ou étrangers, des laboratoires publics ou privés. 


\section{The introduction of emerging currencies into a portfolio: Towards a more complete diversification model}

Sophie Brana, Stéphanie Prat

\section{LAREFI Working Paper CR09-EFI/04}

\section{9}

http://lare-efi.u-bordeaux4.fr

\section{LAREFI}

Université Montesquieu-Bordeaux IV

Bâtiment Recherche Economie

Avenue Léon Duguit - 33608 Pessac 


\begin{abstract}
We draw on portfolio theory and international diversification in order to analyse strategies allowing to reduce emerging economies' exposure to exchange-rate risk. We show in particular that it may be efficient for an investor, in terms of maximising the return-to-risk ratio, to build up a portfolio of emerging-country assets denominated in local currency unhedged against currency risk - compared with a strategy including emerging-country securities denominated in foreign currencies. This strategy would lead to a reduction in the original sin (i.e. the inability of emerging economies to borrow in local currency), and de facto to a reduction in currency mismatches in the balance sheets of emerging economies.
\end{abstract}

\title{
Résumé
}

Nous nous appuyons sur la théorie des portefeuilles et de la diversification internationale afin d'analyser les stratégies permettant de réduire l'exposition des économies émergentes au risque de change. Nous montrons en particulier qu'il peut être efficient pour un investisseur, en termes de maximisation du couple rendement/risque, de constituer un portefeuille d'actifs émergents libellés en monnaie nationale non couvert contre le risque de change par rapport à une stratégie qui inclurait dans le portefeuille des titres émergents libellés en devises. Cette stratégie conduirait à une diminution du péché originel (i.e. l'incapacité des économies émergentes à emprunter en monnaie nationale), et de fait à une réduction des déséquilibres en devises dans les bilans des économies émergentes.

JEL Classification : G11; E44; F34.

Mots-clés : International portfolio diversification, Original Sin, Emerging countries, Downside risk.. 


\section{Introduction}

Balance sheet mismatches in emerging economies, in particular currency mismatches, have played a fundamental role in the repeated crises that have hit these economies for more than ten years. In the late 1990s, Eichengreen and Hausmann (1999) highlighted the fact that a major source of financial fragility in emerging economies was related to the composition in foreign currencies of their external debt. With what they called the original sin theory, the two authors showed that emerging economies were more vulnerable to financial crises than industrialised economies because of their inability to borrow in international capital markets in their own currency. Indeed, the weight of outstanding external commitments denominated in foreign currencies increase financial vulnerability because of the high exposure to foreign exchange and interest rate risk of these economies. It can trigger foreign exchange crises.

For Eichengreen et alii $(2004,2007)$, the original sin primarily reflects the characteristics of international financial markets. In particular, the shortfall in hedging possibilities and the existence of transaction costs result in international investors giving their preference to a small number of currencies when building their portfolio. The portfolio allocation initiated by international investors is thus combined with a transfer of currency risk to emerging economies, which are badly prepared to shoulder this risk. We show, however, within the framework of an approach based on portfolio diversification, that emerging economies might free themselves from such a risk in order to improve their resilience to shocks.

To do so, we show that a strategy consisting in including emerging-country assets, denominated in the local currency and not hedged against currency risk in the portfolio of a foreign investor is not necessarily riskier that an emerging-country asset allocation denominated in foreign currencies. This is because the potential reduction of market risk (currency risk), via the diversification of portfolios composed of emerging securities denominated in the local currency, can be higher than the potential in terms of reduction in credit risk (or default risk) related to an international portfolio composed of emerging securities denominated in foreign currencies, thereby steering the structure of indebtedness of emerging countries towards a structure in the local currency that would be more stable and less risky.

The rest of the article unfolds as follows: section 2 presents the theoretical model we draw upon, by justifying notably our choice to use an asymmetric measure of the portfolio's risk. Section 3 presents the methodology used while we empirically assess the various components of the portfolio's risk in section 4. We draw our conclusions in section 5. 


\section{Theoretical model}

We operate within the framework of portfolio diversification theory proposed by Markowitz $(1952,1959)$ so as to model the return/risk relationship of an internationally diversified portfolio. Initially, Markowitz's model, which is based on the strong hypothesis that economic agents have a quadratic utility function, use the standard deviation (or the variance) of returns on securities to measure a portfolio's risk. A first limitation of this measure is that it takes into account, without making any distinction between them, both upward and downward deviations of returns in comparison with the average. This is inappropriate in terms of assessing the concept of risk from an investor's viewpoint because the attitude of investors varies according to the domain of the utility function, as investors are in particular more sensitive to the losses they incur than to the gains they make (Campbell and Kräussl, 2007) (cf. below). Moreover, the utilisation of the standard deviation as a measure of risk supposes normal distribution of returns. However, returns on emerging securities, in particular bonds, are characterised by negative skewness (Bekaert and Harvey, 1997;

Bekaert, Erb, Harvey and Viskanta, 1998; Burger and Warnock, 2007).

The utilisation of the first- and second-order moments of the distribution of returns in compliance with the portfolio model leads, by consequence in the case of emerging securities, to a non-optimal asset allocation (Bawa and Lindenberg, 1977; Harlow and Rao, 1989; Harlow, 1991). Following Roy (1952), various measures of risk and, accordingly, various models have been proposed to take into consideration the characteristics of distributions of returns on emerging securities, as well as the behaviour of investors with respect to risk, while maintaining the initial two-dimension risk-return relationship (Hwang and Pedersen, 2004). By definition, these measures of risk, so-called downside risk measures, take into account only one part of the distribution of returns rather than the entire distribution. These measures isolate divergences in returns in comparison with a target return only on the left-hand side of the distribution (Harlow, 1991).

Markowitz (1959) notably defined the semi-variance as "the most robust measure of risk from a theoretical viewpoint". It evaluates the average squared deviations of returns below a benchmark. Formally, the author suggested evaluating the semi-variance (SV) of returns in two ways:

$$
\begin{aligned}
& S V_{m}=\frac{1}{T} \sum_{t=1}^{T} \operatorname{Max}\left[0,\left(\bar{R}_{i}-R_{i t}\right)\right]^{2} \\
& S V_{T C}=\frac{1}{T} \sum_{t=1}^{T} \operatorname{Max}\left[0,\left(T C-R_{i t}\right)\right]^{2}
\end{aligned}
$$

Where $R_{i t}$ stands for the return on security $i$ in period $t$ and $T$ for all periods $t . S V_{m}$ evaluates the adverse deviations of returns from the average of returns $\bar{R}_{i}$ (semi-variance in comparison with the average) while $S V_{T C}$ determines the adverse deviations of returns from a benchmark rate of return or an arbitrarily chosen target rate $T C^{1}$. According to this definition, the semi-variance expresses the fact that investors are concerned only with negative deviation from a given and arbitrarily chosen profitability threshold, i.e. investors care only about their potential worst-case returns.

The development of alternative measures if risk, such as semi-variance, made it possible to determine in a more general framework the lower partial moments of order $n$ defined by (Bawa, 1975):

1 TC stands for target rate. 


$$
\operatorname{LPM}(n, T C)=\frac{1}{T} \sum_{t=1}^{T} \operatorname{Max}\left[0,\left(T C-R_{i t}\right)\right]^{n}
$$

$T C$ stands for the chosen target profitability rate, $T$ the number of observations, $n$ the degree of the lower partial moment and $R_{i t}$ the return on security $i$ in period $t$.

From a theoretical viewpoint, the order $n$ of the measure of the Lower Partial Moment $\left(\mathrm{LPM}_{n}\right)$ defines the type of the investor's utility function that is consistent with his degree of risk aversion. The partial moment of order 0 is used for investors attracted by risk (positive derivative of the utility function), while the partial moment of order 1 suits all the utility functions of risk-averse investors (positive derivative of the utility function and negative second derivative). Lastly, the partial moment of order 2 concerns risk-averse investors who also have a preference for a positive asymmetrical distribution of returns ${ }^{2}$ (positive third derivative) (Harlow, 1991; Nawrocki, 1999).

When $n=2$ and the benchmark profitability rate is equal to the average of returns, $\operatorname{LPM}(2, \bar{R})$ represents the previously presented traditional measure of the semi-variance. Generally speaking, the use of lower partial moments allows the restrictive hypotheses of Markowitz's initial portfolio model to be eased, on the one hand with respect to investors' preferences and, on the other hand, with respect to the properties of the distribution functions of the assets returns we are looking at. Ultimately, the average-lower partial moment approach is not only consistent with the attitude of investors with regard to risk but remains valid whatever the characteristics of returns (Harlow, 1991). Recently, Jarrow and Zhao (2006) and Estrada (2007) have shown, in this respect, that the optimal meanvariance portfolio differed significantly from the optimal mean - semi-variance portfolio, notably in the case of a bond portfolio (Jarrow and Zhao, 2006). According to the authors, the mean-variance framework is effectively inappropriate with regard to the management of the risks inherent to this type of asset.

Lastly, we choose to model the portfolio's risk by the lower partial moment of order 2 by estimating the negative deviations of returns from the mean of the distribution ${ }^{3}$ (downside risk measure via semi-standard deviation ${ }^{4}$ ).

Formally, the model, initially described by Bawa and Lindenberg (1977), can be defined as follows:

$$
\left\{\begin{array}{l}
\operatorname{Min}_{w_{i}} L P M_{p}^{R e ́ f}=\sum_{i=1}^{N} \sum_{j=1}^{N} w_{i} w_{j} \operatorname{CoLPM}_{p}\left(R_{i t}^{\text {dom }}+\Delta e_{i}, R_{j t}^{d o m}+\Delta e_{j}\right) \\
\text { Under constraint s } \sum_{\mathrm{i}=1}^{\mathrm{N}} w_{i} E\left(R_{i}\right)=E\left(R_{p}\right) \text { and } \sum_{\mathrm{i}=1}^{\mathrm{N}} \mathrm{w}_{\mathrm{i}}=1 \text { et } \mathrm{w}_{\mathrm{i}}>0 \text { (Non - authorised short sales) }
\end{array}\right.
$$

With

2 Investors take into account the skewness of returns on securities and are generally averse to assets displaying negative skewness, i.e. unlikely but higher potential losses and probable but modest gains.

3 According to Harlow and Rao (1989) the pertinent target profitability is the mean of the distribution of returns.

4 The semi-standard deviation is defined as the square root of semivariance. 


$$
\begin{aligned}
& \operatorname{CoLPM}_{p}\left(R_{i t}^{d o m}+\Delta e_{i}, R_{j t}^{d o m}+\Delta e_{j}\right)= \\
& \sum_{i} w_{i}^{2}\left[\operatorname{Max}\left(0 ; \bar{R}_{i}^{d o m}-R_{i t}^{d o m}\right)^{2}+\operatorname{Min}\left(0 ; \frac{2}{\Delta e_{i}}-\Delta e_{i t}\right)^{2}+2 \sum_{t} \operatorname{Max}\left(0 ; \bar{R}_{i}^{d o m}-R_{i t}^{5}\right) \operatorname{Min}\left(0 ; \overline{\Delta e_{i}}-\Delta e_{i t}\right)\right] \\
& +\sum_{i} \sum_{j}\left[\sum_{t}\left\{\begin{array}{c}
\operatorname{Max}\left(0 ; \bar{R}_{i}^{d o m}-R_{i t}^{d o m}\right){ }^{3} \operatorname{Max}\left(0 ; \bar{R}_{j}^{d o m}-R_{j t}^{d o m}\right)+\operatorname{Max}\left(0 ; \bar{R}_{i}^{d o m}-R_{i t}^{d o m}\right) \operatorname{Min}\left(0 ; \overline{\Delta e_{j}}-\Delta e_{j t}\right) \\
+\operatorname{Min}\left(0 ; \overline{\Delta e_{i}}-\Delta e_{i t}\right) \operatorname{Max}\left(0 ; \bar{R}_{j}^{d o m}-R_{j t}^{d o m}\right)+\operatorname{Min}\left(0 ; \overline{\Delta e_{i}}-\Delta e_{i t}\right) \operatorname{Min}\left(0 ; \overline{\Delta e_{j}}-\Delta e_{j t}\right)
\end{array}\right\}\right]
\end{aligned}
$$

With $R_{i}{ }_{j t}^{d o m}$ the return of asset $i / j$ in period $t$ expressed in the local currency (i.e. the borrower's) and $\Delta e_{i / j t}$ the return of the exchange rate ${ }^{5}$ corresponding to asset $i / j$ over period $t$. $\operatorname{CoLPM}_{p}\left(R_{i t}^{\text {dom }}+\Delta e_{i}, R_{j t}^{\text {dom }}+\Delta e_{j}\right)$ represents the "co-lower partial moment" between the returns on emerging-country assets denominated in the local currency and exchange rate fluctuations.

The risk of an international portfolio unhedged against currency risk is consequently composed of several components:

- the semi-standard deviation (or downside volatility) of returns emerging-country assets, denominated in the local currency or in foreign currencies, which compose the portfolio (term $1)$;

- the downside volatility of exchange rate returns (term 2). If we consider the portfolio of securities denominated in foreign currencies, this term disappears (no currency risk);

- (intra-class) correlations between downside fluctuations in returns on emerging securities (term 3);

- (intra-class) correlations between downside fluctuations in returns on exchange rates (term 4). Likewise, for a portfolio of securities denominated in dollars, this term disappears;

- lastly, (intra-class) correlations between downside movements in returns on emerging securities and returns on the corresponding exchange rates (term 5). This term concerns only the portfolio of emerging-country assets denominated in local currencies.

Terms 6 and 7 of expression (4), which correspond to the covariance between downside movements in returns on emerging securities and downside movements in emerging currencies are supposed to be negligible: this is because it is assumed that downside movements in the fluctuations of currency $j$ (term 6) or $i$ (term 7) are hardly correlated to downside movements in returns of a security denominated in currency $i$ (term 6 ) or $j$ (term 7), for $i \neq j$.

The previously presented model enables us to analyse empirically the advantages of international diversification for a foreign investor.

5 Exchange rate e is defined via an uncertain quotation from the borrower's point of view, i.e. as units of the domestic currency of asset $\mathrm{i} / \mathrm{j}$ per unit of the reference currency. 


\section{Methodology}

The purpose of our approach is to carry out an arbitrage between two types of strategies: a strategy of investments in emerging currencies in comparison with a strategy of investment in dollars. To do so, we use the EMBIG and ELMI+(LC) indices published by J.P. Morgan for various emerging countries. EMBI Global indicators are indices tracking the profitability of sovereign assets of emerging countries (31 December $1993=100$ ) issued in international markets and denominated in dollars, while the ELMI+(LC) indicators are indices tracking the profitability of assets of the domestic money market of emerging economies $(31$ December $1993=100)$ denominated in the local currency.

The ELMI+(LC) indicator corresponds more precisely to the total profitability of the domestic money market instruments denominated in the local currency (J.P. Morgan, 1997). The EMBIG indicator, for its part, refers to the total profitability of assets issued by sovereign or quasi-sovereign entities in emerging economies, and concerns only instruments denominated in US dollars. As for instruments included in the ELMI+(LC) indicator, the assets of the EMBIG indicator have to meet minimum criteria in terms of liquidity and accessibility for foreign investors (J.P. Morgan, 1999).

These two indices, apart from their currency of denomination, are therefore not strictly comparable, as the ELMI+(LC) index covers securities with a shorter duration than instruments eligible for the EMBIG index ${ }^{6}$. Both, however, refer to indices tracking the profitability of emerging debt securities and are regularly compared as alternative investment strategies (Drijkoningen et al. 2006). Moreover they are available for a sample of 11 countries for a period ranging from 1 July 1997 to 31 December 2007, allowing us to compare the performances of two diversified portfolios, one denominated in dollars, the other in emerging currencies, over a relatively long period ${ }^{7}$. The countries included in the sample are South Africa, Argentina, Brazil, China, South Korea, Mexico, the Philippines, Poland, Thailand, Turkey and Venezuela ${ }^{8}$. An investor interested in exposure to emerging-country markets will therefore be able to compare two strategies: exposure to the local public debt or exposure to the local currency. The market of local debt denominated in foreign currencies enables investors to gain access to credit risk on emerging-country markets (as the return is determined by the risk-free rate of US debt plus a credit spread reflecting default risk), while the investment in local currency in emerging-country markets exposes them to a greater extent to currency risk (in addition to credit risk on the local debt).

Our approach breaks down into three stages. Initially, we assess the downside risk of profitability rates of emerging-country assets denominated in the local currency and of emerging-country assets denominated in foreign currencies (term 1 of equation 4). Second, we calculate the downside volatility, measured by the semi-standard deviation, of returns on emerging currencies (term 2 of equation 4). To do so, we use bilateral nominal exchange rates of quoted emerging currencies against the US dollar. The data come from J.P. Morgan with respect to the two profitability indicators, and from Reuters for the bilateral exchange rates. Third, we look at the correlations between downside movements in profitability rates of assets (term 3 of equation 4), between downside fluctuations in exchange rates (term 4) as well as between cross correlations (term 5) which correspond to the three other components of a portfolio's risk. We carry out our study on daily data.

6 The other possible indices - for example, the GBI index — are available only for the recent period and for a smaller number of countries: Brazil, Mexico, Poland, South Africa and Thailand since 2002. This means they cannot be drawn upon to build a real portfolio strategy.

7 Medo et al. (2009) estimate the optimal size of a portfolio is ten assets given the diversification potential.

8 Availability of data has strictly determined choices of countries and the period studied, although a noteworthy point is that we wanted to include the Asian crisis. 


\section{Results}

\subsection{Downside volatility of returns and of emerging currencies}

We carry out a comparative analysis of the downside volatility of the returns of the EMBIG and ELMI+(LC) indicators over the period 1 July 1997 - 31 December 2007 on daily data (i.e. 2,741 trading days). Chart 1 presents changes in the asymmetrical month-on-month (M/M) risk for the two composite indicators of returns for all 11 emerging countries. These composite indicators are calculated as the average of daily returns of each country weighted by their daily market capitalisation. We can see that the downside volatility of returns on domestic securities denominated in the local currency (ELMI+(LC)) is to a large extent lower than the downside volatility of returns on securities traded in international markets (EMBIG), even during a crisis period.

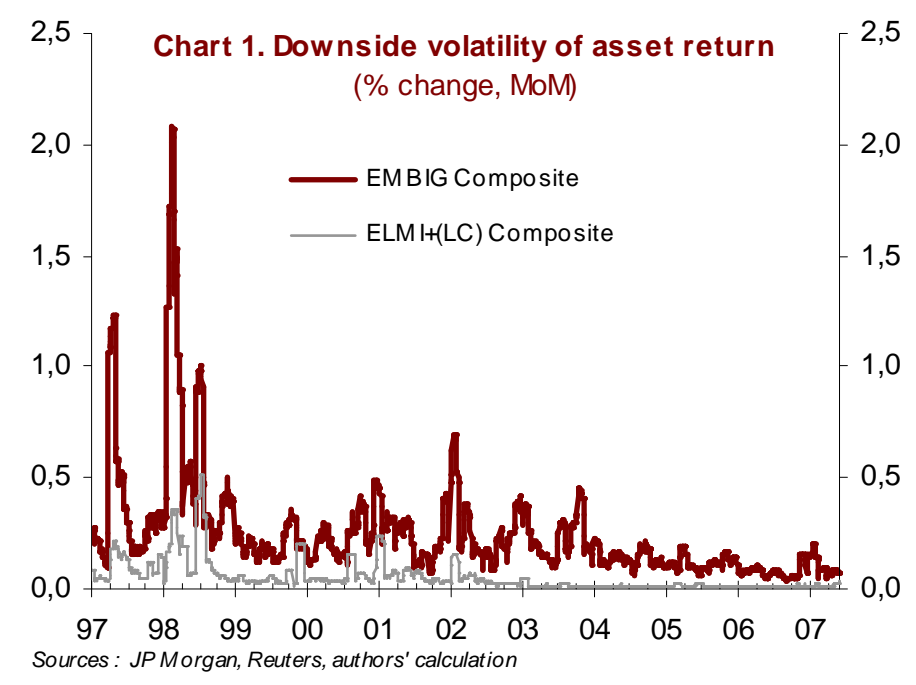

The low volatility of the ELMI+(LC) index is not only due to its short duration, but, as we shall see below, also to the fact that the volatilities of the various currencies offset one another (low intra-class correlation). If we carry out a study on a country-by-country basis, we can see that the economies with the highest downside volatility over the entire period studied here are the ones that have suffered from a financial crisis (Charts 2A to 2F): Argentina, Brazil, Turkey, Thailand and Venezuela. However, the downside risk of domestic securities remains lower than the downside risk of international securities (except for South Korea where the two kinds of downside volatility are comparable): $0.687 \%$ on average versus $1.004 \%$ for Argentina, $0.424 \%$ versus $0.619 \%$ for Turkey, $0.270 \%$ versus $0.543 \%$ for Thailand over the entire period. The downside risk for the ELMI+(LC) composite indicator that covers all 11 countries for its part stood at $0.090 \%$ over the period versus $0.352 \%$ for the EMBIG composite index (Table 1). 
Table 1. Downside volatility calculations

\begin{tabular}{l|cccc}
\hline & $\begin{array}{c}\text { downside volatility(\%) } \\
\text { EMBIG }\end{array}$ & $\begin{array}{c}\text { downside volatility(\%) } \\
\text { ELMI+(LC) }\end{array}$ & $\begin{array}{c}\text { downside volatility(\%) } \\
\text { FX }\end{array}$ & $\begin{array}{c}\text { downside volatility(\%) } \\
\text { ELMI+(LC) + FX }\end{array}$ \\
\hline Index composite & 0,352 & 0,090 & 0,269 & 0,358 \\
\hline
\end{tabular}

Sources: JP Morgan, Reuters and Datastream, authors'calculations 
Charts 2A to 2F: Downside volatility of EMBIG and ELMI+(LC) returns (M/M as \%)

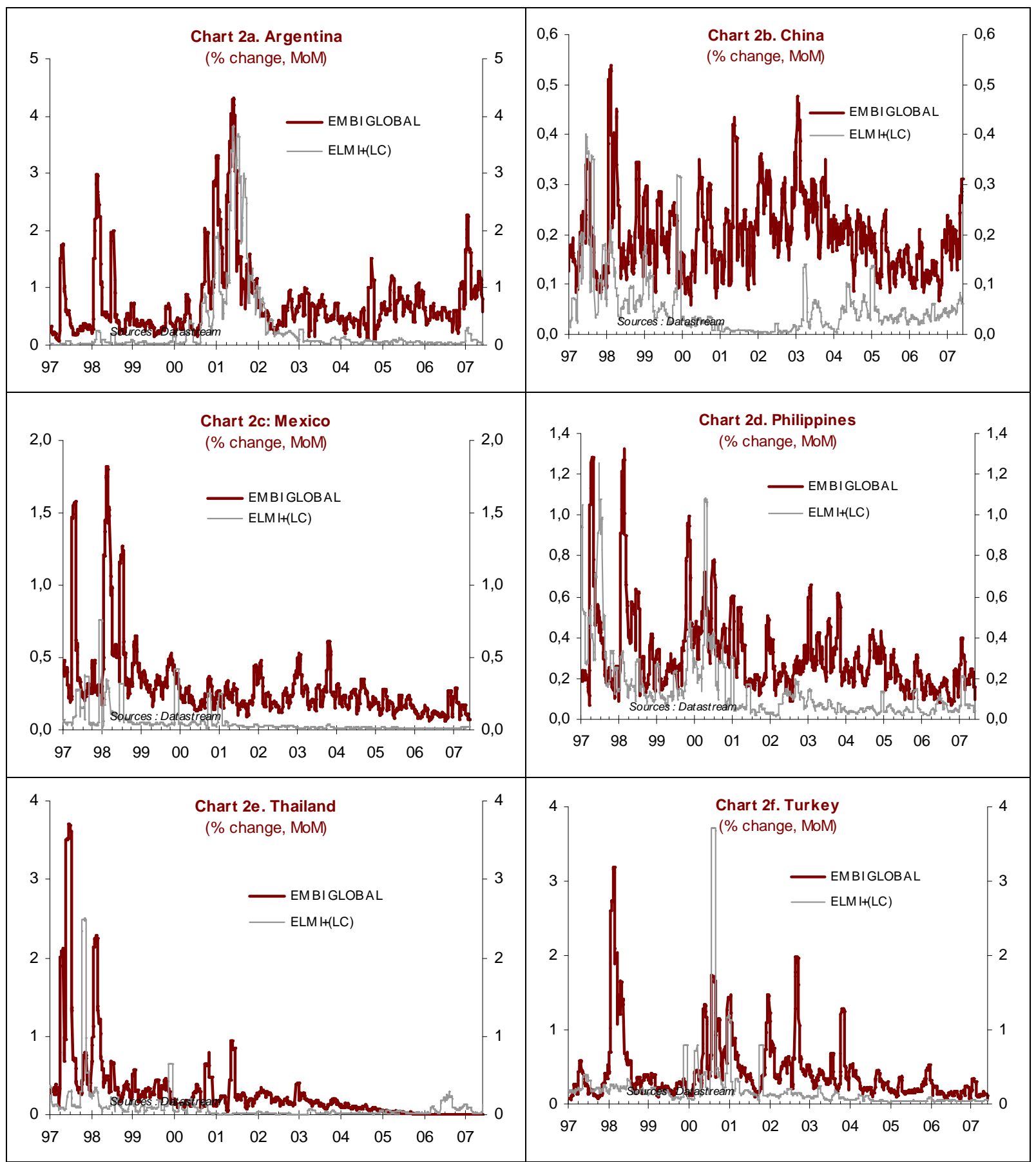

We subsequently assess the downside volatility of emerging currencies, quoted against the US dollar. After surging to all-time high levels during crisis periods (notably in 1997 during the Asian crisis or between 2001 and 2003 in Latin America and in South Africa), the downside volatility of exchange rates has noticeably declined, in these countries, since 2003 and is now below $1 \%$ in monthon-month terms (Charts 3A, 3B and 3C). The average downside volatility of the composite index, for its part, stands at 0.269 , up slightly over the period as a whole (Chart 3 ). 

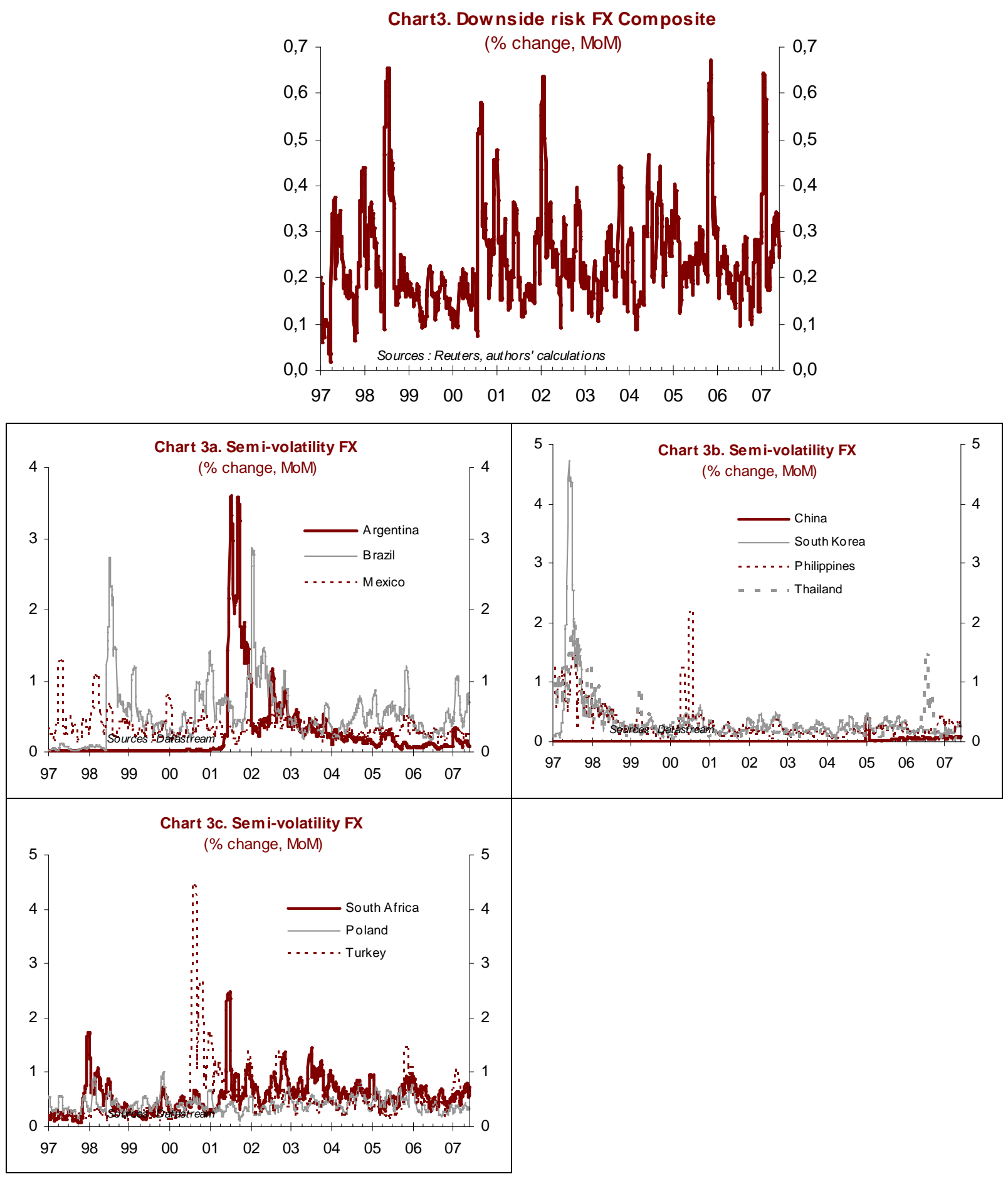

The comparison of [EMBIG] and [ELMI+(LC) + FX] downside volatility shows that the risk related to holding emerging securities denominated in the local currency (composed of the downside volatility of returns and exchange rates) is higher than the one related to holding sovereign securities issued in foreign currencies, except in China, because of currency risk. However, in several countries, the risk differential in favour of EMBIG securities remains low (Brazil, Mexico, Poland and Thailand). A noteworthy point is that the downside volatility of the weighted composite indicator $[$ ELMI+(LC) + FX] is slightly higher than the downside volatility of the EMBIG weighted composite indicator over the period (cf. the first and last columns, Table 1). The analysis, however, remains incomplete. As we have previously emphasised, the assessment of a portfolio's risk must take into account correlations between the various downside movements in returns, i.e. in the possibility of reducing risks via diversification. 

$(F X)$.

We have analysed correlation coefficients between downside movements in returns on EMBIG securities, in returns on ELMI+(LC) securities and in the profitability of exchange rates on daily data. We initially assessed the matrices of correlation coefficients (associated with their p-value in order to determine the significance ${ }^{9}$ of the link) between downside movements in profitability rates of various countries, for the two EMBIG and ELMI+(LC) indicators. To do so, we use Spearman's correlation coefficient, which is more appropriate than the standard one (or Pearson's correlation coefficient) when the distribution of serie is not normal. We are thus able to compare the average level of correlations between downside movements in EMBIG returns and in correlations between downside movements in ELMI+(LC) returns (Tables 2 and 3). We then determine the matrice of the correlation coefficients between downside movements in the return of exchange rates of each emerging currency (Table 4).

Table 2. Corrélation matrix* of downside movements in EMBIG asset returns (over the period)

\begin{tabular}{l|cccccccccc|cc}
\hline \multicolumn{1}{c}{ EMBIG } & $\begin{array}{c}\text { South } \\
\text { Africa }\end{array}$ & Argentina & Brazil & China & $\begin{array}{c}\text { South } \\
\text { Korea }\end{array}$ & Mexico & Philippines & Poland & Thailand & Turkey & Venezuela & Mean EMBIG \\
\hline South Africa & $\mathbf{1}$ & $\mathbf{0 , 1 2 5}$ & $\mathbf{0 , 1 6 9}$ & $\mathbf{0 , 2 8 5}$ & $\mathbf{0 , 2 4 6}$ & $\mathbf{0 , 3 1 5}$ & $\mathbf{0 , 1 8 4}$ & $\mathbf{0 , 4 1 6}$ & $\mathbf{0 , 2 3 6}$ & $\mathbf{0 , 2 5 6}$ & $\mathbf{0 , 1 9 0}$ & 0,242 \\
Argentina & $\mathbf{0 , 1 2 5}$ & $\mathbf{1}$ & $\mathbf{0 , 5 3 8}$ & $\mathbf{0 , 0 5 8}$ & $\mathbf{0 , 1 4 0}$ & $\mathbf{0 , 4 2 2}$ & $\mathbf{0 , 2 9 3}$ & $\mathbf{0 , 1 5 6}$ & $\mathbf{0 , 0 7 1}$ & $\mathbf{0 , 2 5 6}$ & $\mathbf{0 , 4 5 6}$ & 0,251 \\
Brazil & $\mathbf{0 , 1 6 9}$ & $\mathbf{0 , 5 3 8}$ & $\mathbf{1}$ & $\mathbf{0 , 0 9 3}$ & $\mathbf{0 , 1 8 2}$ & $\mathbf{0 , 6 1 7}$ & $\mathbf{0 , 3 8 1}$ & $\mathbf{0 , 1 9 8}$ & $\mathbf{0 , 1 1 0}$ & $\mathbf{0 , 3 8 3}$ & $\mathbf{0 , 5 9 8}$ & 0,327 \\
China & $\mathbf{0 , 2 8 5}$ & $\mathbf{0 , 0 5 8}$ & $\mathbf{0 , 0 9 3}$ & $\mathbf{1}$ & $\mathbf{0 , 3 9 4}$ & $\mathbf{0 , 3 4 6}$ & $\mathbf{0 , 1 4 2}$ & $\mathbf{0 , 4 0 9}$ & $\mathbf{0 , 4 6 8}$ & $\mathbf{0 , 0 8 0}$ & $\mathbf{0 , 1 0 6}$ & 0,238 \\
South Korea & $\mathbf{0 , 2 4 6}$ & $\mathbf{0 , 1 4 0}$ & $\mathbf{0 , 1 8 2}$ & $\mathbf{0 , 3 9 4}$ & $\mathbf{1}$ & $\mathbf{0 , 3 1 2}$ & $\mathbf{0 , 2 1 7}$ & $\mathbf{0 , 3 0 5}$ & $\mathbf{0 , 5 2 7}$ & $\mathbf{0 , 1 4 3}$ & $\mathbf{0 , 1 8 6}$ & 0,265 \\
Mexico & $\mathbf{0 , 3 1 5}$ & $\mathbf{0 , 4 2 2}$ & $\mathbf{0 , 6 1 7}$ & $\mathbf{0 , 3 4 6}$ & $\mathbf{0 , 3 1 2}$ & $\mathbf{1}$ & $\mathbf{0 , 3 7 8}$ & $\mathbf{0 , 3 8 2}$ & $\mathbf{0 , 2 6 1}$ & $\mathbf{0 , 3 4 3}$ & $\mathbf{0 , 5 1 8}$ & 0,389 \\
Philippines & $\mathbf{0 , 1 8 4}$ & $\mathbf{0 , 2 9 3}$ & $\mathbf{0 , 3 8 1}$ & $\mathbf{0 , 1 4 2}$ & $\mathbf{0 , 2 1 7}$ & $\mathbf{0 , 3 7 8}$ & $\mathbf{1}$ & $\mathbf{0 , 1 9 6}$ & $\mathbf{0 , 1 5 4}$ & $\mathbf{0 , 3 4 5}$ & $\mathbf{0 , 3 1 9}$ & 0,261 \\
Poland & $\mathbf{0 , 4 1 6}$ & $\mathbf{0 , 1 5 6}$ & $\mathbf{0 , 1 9 8}$ & $\mathbf{0 , 4 0 9}$ & $\mathbf{0 , 3 0 5}$ & $\mathbf{0 , 3 8 2}$ & $\mathbf{0 , 1 9 6}$ & $\mathbf{1}$ & $\mathbf{0 , 2 7 5}$ & $\mathbf{0 , 1 6 1}$ & $\mathbf{0 , 2 0 0}$ & 0,270 \\
Thailand & $\mathbf{0 , 2 3 6}$ & $\mathbf{0 , 0 7 1}$ & $\mathbf{0 , 1 1 0}$ & $\mathbf{0 , 4 6 8}$ & $\mathbf{0 , 5 2 7}$ & $\mathbf{0 , 2 6 1}$ & $\mathbf{0 , 1 5 4}$ & $\mathbf{0 , 2 7 5}$ & $\mathbf{1}$ & $\mathbf{0 , 0 9 0}$ & $\mathbf{0 , 1 2 7}$ & 0,232 \\
Turkey & $\mathbf{0 , 2 5 6}$ & $\mathbf{0 , 2 5 6}$ & $\mathbf{0 , 3 8 3}$ & $\mathbf{0 , 0 8 0}$ & $\mathbf{0 , 1 4 3}$ & $\mathbf{0 , 3 4 3}$ & $\mathbf{0 , 3 4 5}$ & $\mathbf{0 , 1 6 1}$ & $\mathbf{0 , 0 9 0}$ & $\mathbf{1}$ & $\mathbf{0 , 3 3 1}$ & 0,239 \\
Venezuela & $\mathbf{0 , 1 9 0}$ & $\mathbf{0 , 4 5 6}$ & $\mathbf{0 , 5 9 8}$ & $\mathbf{0 , 1 0 6}$ & $\mathbf{0 , 1 8 6}$ & $\mathbf{0 , 5 1 8}$ & $\mathbf{0 , 3 1 9}$ & $\mathbf{0 , 2 0 0}$ & $\mathbf{0 , 1 2 7}$ & $\mathbf{0 , 3 3 1}$ & $\mathbf{1}$ & 0,303 \\
\hline \hline Mean EMBIG & 0,242 & 0,251 & 0,327 & 0,238 & 0,265 & 0,389 & 0,261 & 0,270 & 0,232 & 0,239 & 0,303 & $\mathbf{0 , 2 7 4}$ \\
\hline
\end{tabular}

${ }^{*}:$ bold characters mean significant correlation between countries at $99 \%$ confidence level

Source: authors' calculations

Table 3. Corrélation matrix* of downside movements in ELMI+(LC) asset returns (over the period)

\begin{tabular}{|c|c|c|c|c|c|c|c|c|c|c|c|c|}
\hline ELMI+(LC) & $\begin{array}{l}\text { South } \\
\text { Africa }\end{array}$ & Argentina & Brazil & China & $\begin{array}{l}\text { South } \\
\text { Korea }\end{array}$ & Mexico & Philippines & Poland & Thailand & Turkey & Venezuela & $\begin{array}{c}\text { Mean } \\
\text { ELMI+(LC) }\end{array}$ \\
\hline South Africa & 1 & 0,119 & 0,140 & 0,130 & 0,193 & 0,306 & 0,146 & 0,342 & 0,142 & 0,043 & 0,143 & 0,170 \\
\hline Argentina & 0,119 & 1 & 0,115 & 0,037 & 0,040 & 0,154 & 0,056 & 0,129 & 0,056 & 0,050 & 0,110 & 0,087 \\
\hline Brazil & 0,140 & 0,115 & 1 & 0,063 & 0,104 & 0,216 & 0,076 & 0,194 & 0,064 & 0,084 & 0,116 & 0,117 \\
\hline China & 0,130 & 0,037 & 0,063 & 1 & 0,195 & 0,134 & 0,153 & 0,127 & 0,144 & $-0,002$ & 0,042 & 0,102 \\
\hline South Korea & 0,193 & 0,040 & 0,104 & 0,195 & 1 & 0,177 & 0,111 & 0,226 & 0,166 & 0,027 & 0,135 & 0,137 \\
\hline Mexico & 0,306 & 0,154 & 0,216 & 0,134 & 0,177 & 1 & 0,141 & 0,322 & 0,152 & 0,042 & 0,165 & 0,181 \\
\hline Philippines & 0,146 & 0,056 & 0,076 & 0,153 & 0,111 & 0,141 & 1 & 0,145 & 0,152 & 0,046 & 0,130 & 0,116 \\
\hline Poland & 0,342 & 0,129 & 0,194 & 0,127 & 0,226 & 0,322 & 0,145 & 1 & 0,117 & 0,006 & 0,226 & 0,183 \\
\hline Thailand & 0,142 & 0,056 & 0,064 & 0,144 & 0,166 & 0,152 & 0,152 & 0,117 & 1 & $-0,007$ & 0,054 & 0,104 \\
\hline Turkey & 0,043 & 0,050 & 0,084 & $-0,002$ & 0,027 & 0,042 & 0,046 & 0,006 & $-0,007$ & 1 & 0,107 & 0,040 \\
\hline Venezuela & 0,143 & 0,110 & 0,116 & 0,042 & 0,135 & 0,165 & 0,130 & 0,226 & 0,054 & 0,107 & 1 & 0,123 \\
\hline $\begin{array}{c}\text { Mean } \\
\text { ELMI+(LC) }\end{array}$ & 0,170 & 0,087 & 0,117 & 0,102 & 0,137 & 0,181 & 0,116 & 0,183 & 0,104 & 0,040 & 0,123 & 0,124 \\
\hline
\end{tabular}

Source: authors' calculations

${ }^{9}$ We have set the significance threshold at $1 \%$. 
Table 4. Corrélation matrix* of downside movements in FX returns (over the period)

\begin{tabular}{|c|c|c|c|c|c|c|c|c|c|c|c|c|}
\hline $\mathrm{FX}$ & $\begin{array}{l}\text { South } \\
\text { Africa }\end{array}$ & Argentina & Brazil & China & $\begin{array}{l}\text { South } \\
\text { Korea }\end{array}$ & Mexico & Philippines & Poland & Thailand & Turkey & Venezuela & Mean FX \\
\hline South Africa & 1 & 0,063 & 0,203 & 0,001 & 0,082 & 0,230 & 0,087 & 0,324 & 0,123 & 0,292 & 0,032 & 0,144 \\
\hline Argentina & 0,063 & 1 & 0,112 & 0,006 & 0,020 & 0,060 & $-0,012$ & 0,046 & $-0,013$ & 0,057 & 0,024 & 0,036 \\
\hline Brazil & 0,203 & 0,112 & 1 & 0,008 & 0,058 & 0,331 & 0,064 & 0,165 & 0,035 & 0,231 & 0,005 & 0,121 \\
\hline China & 0,001 & 0,006 & 0,008 & 1 & 0,052 & 0,004 & 0,035 & 0,005 & 0,036 & 0,020 & $-0,033$ & 0,013 \\
\hline South Korea & 0,082 & 0,020 & 0,058 & 0,052 & 1 & 0,089 & 0,241 & 0,124 & 0,279 & 0,052 & 0,029 & 0,103 \\
\hline Mexico & 0,230 & 0,060 & 0,331 & 0,004 & 0,089 & 1 & 0,075 & 0,144 & 0,104 & 0,162 & 0,017 & 0,122 \\
\hline Philippines & 0,087 & $-0,012$ & 0,064 & 0,035 & 0,241 & 0,075 & 1 & 0,104 & 0,293 & 0,056 & $-0,024$ & 0,092 \\
\hline Poland & 0,324 & 0,046 & 0,165 & 0,005 & 0,124 & 0,144 & 0,104 & 1 & 0,188 & 0,302 & 0,042 & 0,144 \\
\hline Thailand & 0,123 & $-0,013$ & 0,035 & 0,036 & 0,279 & 0,104 & 0,293 & 0,188 & 1 & 0,079 & 0,031 & 0,115 \\
\hline Turkey & 0,292 & 0,057 & 0,231 & 0,020 & 0,052 & 0,162 & 0,056 & 0,302 & 0,079 & 1 & 0,030 & 0,128 \\
\hline Venezuela & 0,032 & 0,024 & 0,005 & $-0,033$ & 0,029 & 0,017 & $-0,024$ & 0,042 & 0,031 & 0,030 & 1 & 0,015 \\
\hline Mean FX & 0,144 & 0,036 & 0,121 & 0,013 & 0,103 & 0,122 & 0,092 & 0,144 & 0,115 & 0,128 & 0,015 & 0,094 \\
\hline
\end{tabular}

The comparison of results between Tables 2 and 3 shows a significant difference between the coefficients of average intra-class correlations of the two types of return. The coefficients are close to 1 for 2.2 between downside movements in returns on securities denominated in the local currency (average correlation for the ELMI+(LC) indicator of around 0.124) and downside movements in returns on securities denominated in foreign currencies (average correlation for the EMBIG indicator of around 0.274). Another important difference is that there is no upward trend in correlations when the return decreases for ELMI indices, while unfavourable periods lead to contagion effects on EMBIG indices. According to J.P. Morgan (1999), this situation is explain by the fact that investors invest in an asset class (debt securities) when they invest in the EMBIG, to a greater extent than they invest in a local perspective (investment in a country). They will therefore be more sensitive to international events and notably to movements in the US Treasury market.

An in-depth study of the average correlations of each country for the two indicators throughout the period shows, without any exception, the low level of coefficients associated with domestic securities in comparison with international securities. In particular, the deviation between correlation coefficients is significant in the entire period for Turkey ( 0.239 versus 0.040$)$, Argentina ( 0.251 versus $0.087)$, Venezuela (0.303 versus 0.123 ) or Brazil (0.327 versus 0.117$)$. Moreover, the downside correlations of EMBIG securities are all significantly positive.

An analysis of correlation coefficients for emerging currencies (Table 4) shows a low average correlation between downside movements in exchange rates throughout the period (of around 0.094). In particular, the downside movements in currencies in Argentina, China, the Philippines and Venezuela are close to zero over the period. Conversely, currencies with the most highly correlated exchange rates are those of South Africa and Poland with an average correlation coefficient of 0.144 over the period.

As a result, the average correlations associated with emerging securities denominated in the local currency, for which one also needs to take into account correlations between fluctuations in exchange rates, are lower for the period as a whole than average intra-class correlations of securities denominated in foreign currencies $(0.274$ versus $0.124+0.094=0.218)$. These results add credence to the argument calling for a greater diversification of portfolios in favour of emerging securities denominated in the local currency insofar as one part of risk is minimised. However, before drawing a definitive conclusion, we need to analyse the last component of the overall risk of a portfolio unhedged against currency risk: the cross correlations between downside movements in profitability rates of emerging-country assets and downside movements in corresponding currencies (term 5 of equation 4).

\subsection{Correlations between downside movements in returns $(E L M I+(L C))$ and in corresponding} currencies $(F X)$ 
The last component of the risk of an international portfolio is determined by the level of cross correlations between downside movements in returns on emerging securities expressed in the local currency and downside movements in the corresponding emerging currencies.

We have empirically assessed the degree of correlation between these two variables by calculating the Spearman coefficients for each country of the sample throughout the period (July 1997-December 2007). The p-values calculated for the correlation coefficients enable us to test the null hypothesis of a correlation not significantly different from zero. The results are presented in the following Table ${ }^{10}$ :

Table 5. Cross correlations ELMI+(LC) - FX over the period

\begin{tabular}{lc}
\hline \multicolumn{1}{c}{ Cross correlations } & $\begin{array}{c}\text { ELMI+(LC) July 1997 - } \\
\text { December 2007 (11 countries) }\end{array}$ \\
\hline Rand - South Africa & $-0,035$ \\
Peso - Argentina & 0,045 \\
Real - Brazil & $-0,020$ \\
Yuan - China & $\mathbf{0 , 0 6 0}$ \\
Won - South Korea & $-0,045$ \\
Peso - Mexico & $-\mathbf{0 , 1 7 6}$ \\
Peso - Philippines & $-\mathbf{0 , 1 6 7}$ \\
Zloty - Poland & $-0,020$ \\
Baht - Thailand & $-\mathbf{0 , 1 3 2}$ \\
Lire - Turkey & 0,029 \\
Bolivar - Venezuela & $-0,009$ \\
\hline \hline Mean correlation & $-\mathbf{0 , 0 4 3}$ \\
\hline
\end{tabular}

Cross correlations are the last component of the risk of a portfolio including emerging sovereign securities denominated in local currencies. Over the period as a whole, only one country posts a significantly positive cross correlation: China. This means that the asymmetrical change in this country's returns is quite significantly correlated to an asymmetrical change in the local currency's exchange rate. Conversely, Mexico, the Philippines and Thailand post a significantly negative cross correlation that helps lower the portfolio's overall risk. Over the period as a whole, eight countries out of eleven post a negative cross correlation. The average cross correlation is ultimately negative and stands at -0.043 .

All in all, we can empirically compare the various levels of risks international investors face by drawing on all the results of the five components of portfolio risk (Table 6). If the component of risk defined by the downside volatility of returns and of exchange rates are approximately similar for the two types of securities we have looked into (downside volatility for the EMBIG composite indicator is close to 0.352 while the downside volatility for the ELMI+(LC) composite indicator + the FX composite indicator is approximately 0.358 ), the comparison of the other components of overall risk determined by the levels of correlations enables us to draw a distinction between these two types of assets.

Over the period as a whole, the correlation associated with EMBIG securities is close to 0.274 (Table 2), while for ELMI+(LC) securities unhedged against currency risk, the average correlation stands at 0.175 (0.218-0.043), i.e. more than 1/3rd lower than that of EMBIG securities.

\begin{tabular}{|c|c|c|c|c|c|c|c|c|}
\hline & \multicolumn{2}{|c|}{ Downside volatility } & \multicolumn{2}{|c|}{ Intra-class correlations } & \multicolumn{2}{|c|}{ Cross correlations } & \multicolumn{2}{|c|}{ Global portfolio risk } \\
\hline & EMBIG & ELMI-FX & EMBIG & ELMI-FX & EMBIG & ELMI-FX & EMBIG & ELMI-FX \\
\hline Composite index & 0,352 & 0,358 & 0,274 & 0,218 & - & $-0,043$ & 0,627 & 0,533 \\
\hline
\end{tabular}

\footnotetext{
${ }^{10}$ Coefficients in bold type show a significant correlation at the $1 \%$ threshold. Correlation coefficients are calculated according to Spearman's method, used when series are not distributed normally.
} 
All in all, the overall risk of a diversified portfolio made up of emerging securities denominated in foreign currencies is higher for the sample of countries we have studied than the overall risk of a portfolio made up of emerging-county sovereign bond securities denominated in the local currencies unhedged against currency risk over the period July 1997-December 2007 (0.627 versus 0.533 ). By consequence, it would have been in the interest of an investor not to hedge against currency risk over the period under consideration.

\section{Conclusion}

At this point, portfolio and international diversification theory becomes fully meaningful: via a process of risk ranking, we can show that the downside potential for market risk, achieved by an international diversification of portfolios that includes emerging-country assets denominated in local currencies, is higher than the downside potential for the credit risk shouldered by an investor who includes exclusively in his portfolio emerging securities denominated in foreign currencies. Such a strategy nevertheless supposes building a diversified enough portfolio, over a relatively long period. The advantages gained from diversification due to low correlations between changes in profitability rates of emerging securities, but also with other asset classes, should induce investors to modify structurally their asset allocations in favour of securities denominated in the local currency in order to improve the efficiency of their portfolio.. Such a strategy could reduce the "original sin" these economies face. 


\section{Bibliography}

Bawa, V.S., 1975. "Optimal Rules for Ordering Uncertain Prospects”, Journal of Financial Economics, vol. 2(1), pp. 95-121.

Bawa V.S. et E.B. Lindenberg, 1977. "Capital Market Equilibrium in a Mean-Lower Partial Moment Framework", Journal of Financial Economics, vol. 5[2], pp. 189-200.

Bekaert G. et C. R. Harvey, 1997. "Emerging Equity Market Volatility", NBER Working Papers 5307, National Bureau of Economic Research, Inc, revised.

Bekaert G., C.B. Erb, C.R. Harvey et T.E. Viskanta, 1998. "Distributional Characteristics of Emerging Market Returns and Asset Allocation", Journal of Portfolio Management, Winter, pp. 102116.

Burger J.D. et F.E. Warnock, 2007. "Foreign Participation in Local Currency Bond Markets", Review of Financial Economics, vol. 16[3], pp. 291-304.

Campbell R.A. et R. Kräussl, 2007. "Revisiting the Home Bias Puzzle - Downside Equity Risk", Journal of International Money and Finance, vol. 26[7], November, pp. 1239-1260.

R., Oosterwoud M., van der Made B. (2006), "Accessing local markets in emerging market debt", Focus on Emerging Asset Classes, PWM, juin, pp.23-25.

Eichengreen B. et R. Hausmann, 1999. "Exchange Rate and Financial Fragility", Proceedings, Federal Reserve Bank of Kansas City, pp.329-368.

Eichengreen B., R. Hausmann et U. Panizza, 2004. "The Pain of Original Sin", in Eichengreen et Hausmann [éd.], Other People's Money: Debt Denomination and Financial Instability in Emerging Market Economies, Chicago, The university of Chicago Press.

Eichengreen B., R. Hausmann et U. Panizza, 2007. "Currency Mismatches, Debt Intolerance and Original Sin: Why They Are Not the Same and Why it Matters", in Edwards [éd.], Capital Controls and Capital Flows in Emerging Economies: Policies, Practices and Consequences, Chicago, The university of Chicago Press.

Estrada J., 2007. "Mean-Semivariance Behaviour: Downside Risk and Capital Asset Pricing" International Review of Economics \& Finance, vol. 16[2], pp. 169-185.

Harlow W. V. et R. K. S. Rao, 1989. "Asset Pricing in a Generalized Mean-Lower Partial Moment Framework: Theory and Evidence", Journal of Financial and Quantitative Analysis, vol. 24, No. 3, September, pp. 285-311.

Harlow W.V., 1991. "Asset Allocation in a Downside Risk Framework", Financial Analysts Journal, September-October, pp.28-40.

Hwang S. et C.S. Pedersen, 2004. "Asymmetric Risk Measures when Modelling Emerging Markets Equitites: Evidence For Regional and Timing Effects”, Emerging Markets Review, vol. 5[1], pp. 109-128.

Jarrow R. et F. Zhao, 2006. "Downside Loss Aversion and Portfolio Management", Management Science, vol. 52, Issue 4, pp. 558-566.

Medo M., Yeung C.H., Zhang Y-C, 2009. "How to quantify the influence of correlations on investment diversification", International Review of Financial Analysis, vol. 18, pp.34-39.

J.P. Morgan, 1997. "The Emerging Local Markets Index Plus", J.P.Morgan Securities Inc, Emerging Market Research, November 19.

J.P. Morgan, 1999. "Introducing the JP Morgan Emerging Markets Bond Index Global (EMBI Global)", J.P.Morgan Securities Inc, Emerging Market Research, August 3.

Markowitz H., 1952. "Portfolio Selection", Journal of Finance, 7 [1], pp. 77-91.

Markowitz H., 1959. Portfolio Selection and Efficient Diversification, J. Willey \& Sons.

Nawrocki, D., 1999. "A Brief History of Downside Risk Measures”, Journal of Investing, vol.8(3), Fall, pp. 9-25. 
Roy A.D., 1952. "Safety First and the Holding of Assets", Econometrica 20, No. 3, pp. 431449. 